\section{Insufficient evidence for NTCP activity in stellate cells}

We read with interest the study of Salhab postulating the sodium $+/$ taurocholate cotransporting polypeptide (NTCP) as novel therapeutic target against liver fibrosis. ${ }^{1}$ The authors report functional expression of the bile acid uptake transporter NTCP in primary human hepatic stellate and LX2 cells and suggest a role for NTCP-mediated bile salt uptake and consequent activation of stellate cells in the pathogenesis of liver fibrosis.

The authors used a commercially available antibody against human NTCP for immunofluorescent stainings and Western blots, fluorescence activated cell sorting (FACS) analysis and as a neutralising antibody in bile salt uptake experiments. Remarkably, despite high immunopositive signals, no cell surface signal was observed in the immunofluorescent stainings. Using this antibody, the authors show complete inhibition of NTCP-mediated bile salt uptake in LX2 cells, whereas the epitope to which the antibody was raised is mostly intracellular. In addition, the NTCP migration pattern shown on Western blot deviates from the characteristic diffuse NTCP migration pattern seen in hepatocellular lysates as well as in NTCPoverexpressing cell lines. ${ }^{2}$ NTCP is a heavily glycosylated protein and we have previously shown that this glycosylation is essential for its plasma membrane trafficking and activity. ${ }^{2}$

A highly interesting though puzzling observation is the beneficial effect of NTCP neutralisation on fibrosis development in a $\mathrm{CCL}_{4}$ mouse model. The antibody used to neutralise mouse NTCP was raised in rabbits and targets a synthetic peptide corresponding to the intracellular $\mathrm{C}$ terminal region of mouse NTCP. Therefore, it is unclear how this antibody could operate as a blocking antibody. The effects observed in the mouse model of fibrosis may be related to an acute inflammatory response elicited by the use of rabbit antibodies in mice. No antibody control was used in this experiment. We and others have previously demonstrated that both the NTCP-mediated as well as Oatp1a/1bmediated bile salt uptake machinery is rapidly downregulated in inflammatory conditions, which may explain the modestly elevated taurocholic acid (TCA) elevation seen in $\mathrm{CCL}_{4} /$ anti-NTCP injected mice.
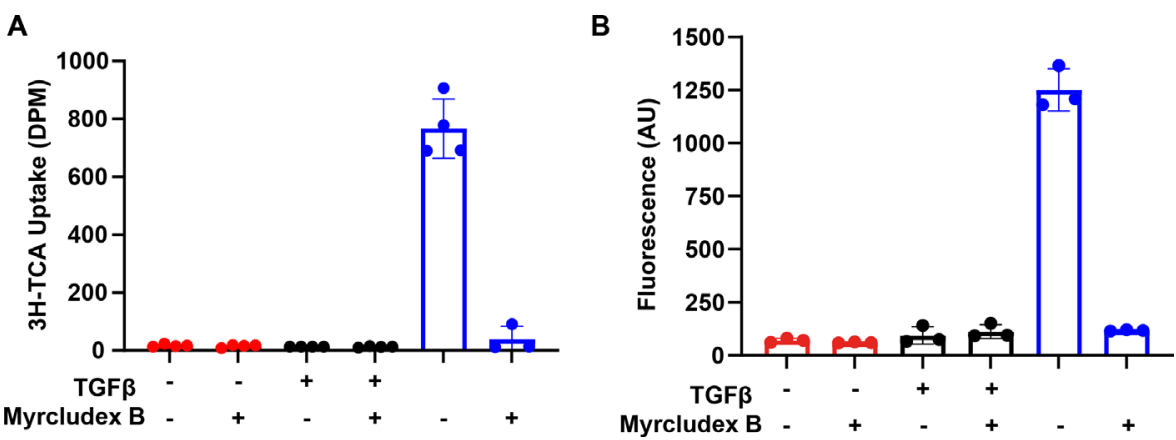

Figure 1 Myrcludex B does not inhibit either ${ }^{3} \mathrm{H}-\mathrm{TCA}$ or Tauro-NOR-THCA-24-DBD uptake radiolabelled TCA (A) or fluorescent Tauro-NOR-THCA-24-DBD (B) uptake in LX2 cells with or without TGF $\beta$ activation with U2OS_HA-hNTCP cells as a positive control. DPM, desintegrations per minute;TGF, transforming growth factor.

Because our research interests centre around hepatobiliairy transport processes, including NTCP function, we studied NTCP cell surface presence and activity in LX2 cells without relying on antibodies (online supplemental material). We performed bile salt uptake assays in the presence and absence of the specific and wellcharacterised NTCP inhibitory peptide Myrcludex B (also called bulevirtide). ${ }^{3}$ In contrast to U2OS cells overexpressing human NTCP, ${ }^{3} \mathrm{H}$-TCA as well as TauroNOR-THCA-24-DBD uptake was at background levels in LX2 cells, independent of TGFß-induced activation, and could not be further blocked with Myrcludex B (figure 1A,B). TGF $\beta$-activated LX2 cells did not show any plasma membrane labelling on incubation with FITC-labelled Myrcludex B (figure 2), in contrast to NTCP-positive U2OS cells. This suggests that no, also no low-abundance subsets of, NTCPpositive cells were present in this cell population. Our bile salt uptake data are in sharp contrast to the data provided by the authors, where the culture medium containing $100 \mu \mathrm{M}$ TCA is completely depleted from TCA after $45 \mathrm{~min}$, supposedly due to uptake activity of NTCP. If we (safely) assume that the height of the cells is $<1 \%$ of the total height of the culture medium, the intracellular TCA concentration would need to reach at least $10 \mathrm{mM}$ inside these NTCP-positive stellate cells, an unlikely scenario as this is above the critical micelle concentration of TCA. ${ }^{4}$

In conclusion, we believe that a direct role of NTCP activity in stellate cells contributing to fibrosis is not proven by the experiments presented by Salhab et al. More investigations using specific inhibitors and better controlled conditions are necessary before we can pursue
LX2 without TGF $\beta$
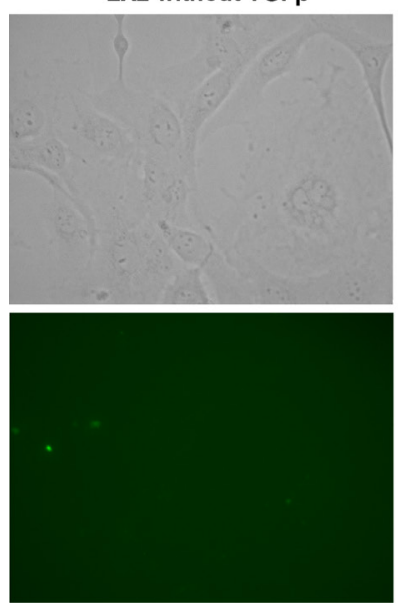

LX2 with TGF

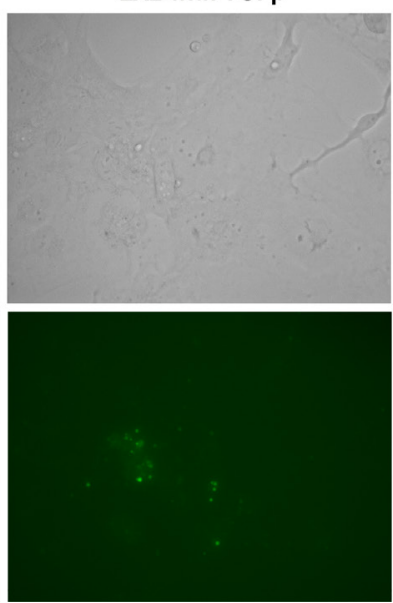

U2OS_NTCP

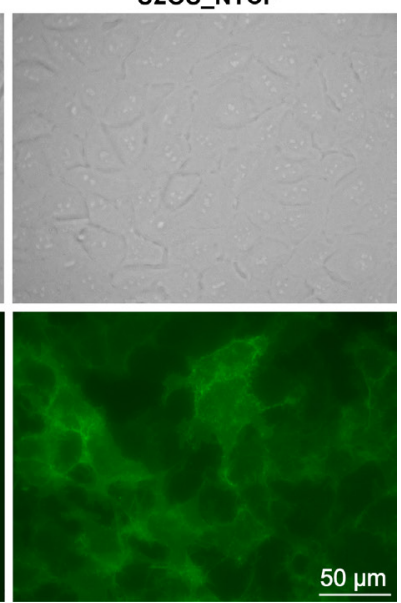

Figure 2 Myrcludex B binds to the cell surface of NTCP-positive U2OS cells, but not LX2 cells. Bright field (top) and fluorescent (bottom) microscopy images showing strong plasma membrane binding of Myrcludex B-FITC in NTCP positive U2OS but not LX2 cells. The latter only shows non-specific intracellular signal. FITC, fluorescein isothiocyanate; NTCP, sodium+/taurocholate cotransporting polypeptide, 
NTCP in stellate cells as a promising antifibrotic target.

\section{Roni F Kunst, ${ }^{1,2}$ Coen C Paulusma, ${ }^{1,2}$} Stan F J van de Graaf $\odot^{1,2}$

${ }^{1}$ Amsterdam Gastroenterology, Endocrinology, Metabolism, Amsterdam University Medical Centers, Amsterdam, The Netherlands

${ }^{2}$ Tytgat Institute and Department of Gastroenterology and Hepatology, Amsterdam UMC Locatie AMC, Amsterdam, North Holland, The Netherlands

Correspondence to Dr Stan F J van de Graaf, Tytgat Institute for Liver and Intestinal Research, Amsterdam UMC Locatie AMC, Amsterdam 1105 AZ, North Holland, The Netherlands;

k.f.vandegraaf@amsterdamumc.nl

Contributors All authors substantially contributed to the conception, design of the work, the acquisition, analysis and interpretation of data. All authors together drafted the manuscript, provided fedback and agree with the final version for submission and are acountable for its content.

Funding The authors have not declared a specific grant for this research from any funding agency in the public, commercial or not-for-profit sectors.

Competing interests None declared.

Patient consent for publication Not applicable.

Ethics approval This study does not involve human participants.

Provenance and peer review Not commissioned; externally peer reviewed.
Supplemental material This content has been supplied by the author(s). It has not been vetted by BMJ Publishing Group Limited (BMJ) and may not have been peer-reviewed. Any opinions or recommendations discussed are solely those of the author(s) and are not endorsed by BMJ. BMJ disclaims all liability and responsibility arising from any reliance placed on the content. Where the content includes any translated material, BMJ does not warrant the accuracy and reliability of the translations (including but not limited to local regulations, clinical guidelines, terminology, drug names and drug dosages), and is not responsible for any error and/or omissions arising from translation and adaptation or otherwise.

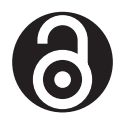

\section{OPEN ACCESS}

Open access This is an open access article distributed in accordance with the Creative Commons Attribution Non Commercial (CC BY-NC 4.0) license, which permits others to distribute, remix, adapt, build upon this work non-commercially, and license their derivative works on different terms, provided the original work is properly cited, appropriate credit is given, any changes made indicated, and the use is non-commercial. See: http://creativecommons.org/ licenses/by-nc/4.0\%.

(c) Author(s) (or their employer(s)) 2021. Re-use permitted under CC BY-NC. No commercial re-use. See rights and permissions. Published by BMJ.
Additional supplemental material is published online only. To view, please visit the journal online (http://dx.doi.org/10.1136/gutjnl-2021-326452).

\section{(A) Check for updates}

To cite Kunst RF, Paulusma CC, van de Graaf SFJ. Gut Epub ahead of print: [please include Day Month Year]. doi:10.1136/gutjnl-2021-326452

Received 29 October 2021

Accepted 29 November 2021

Gut 2021;0:1-2. doi:10.1136/gutjnl-2021-326452

ORCID iD

Stan F J van de Graaf http://orcid.org/0000-00034238-4359

\section{REFERENCES}

1 Salhab A, Amer J, Lu Y, et al. Sodium+/taurocholate cotransporting polypeptide as target therapy for liver fibrosis. Gut 2021. doi:10.1136/gutjnl-2020-323345. [Epub ahead of print: 15 Jul 2021] (published Online First: 2021/07/17).

2 Appelman MD, Chakraborty A, Protzer U, et al. NGlycosylation of the $\mathrm{Na}$--taurocholate cotransporting polypeptide (Ntcp) determines its trafficking and stability and is required for hepatitis B virus infection. PLoS One 2017:12:e0170419.

3 Donkers JM, Appelman MD, van de Graaf SFJ. Mechanistic insights into the inhibition of Ntcp by myrcludex B. JHEP Rep 2019;1:278-85.

4 Meyerhoffer SM, McGown LB. Critical micelle concentration behavior of sodium taurocholate in water. Langmuir 1990;6:187-91. 